Ekonomica Sharia Volume 5 Nomor 1 Edisi Agustus 2019 | 1

\title{
PENENTUAN KINERJA ORGANISASI PEMERINTAH DAERAH DI KABUPATEN MUSI BANYUASIN, PROVINSI SUMATERA SELATAN
}

\author{
${ }^{1}$ Indra. S., ${ }^{2}$ Sulaiman, ${ }^{3}$ Chandra Satria, ${ }^{4}$ M. Thoyib, ${ }^{5}$ Ade L., ${ }^{6}$ Adit A \\ 1,2,4,5,6 Politeknik Negeri Sriwijaya Palembang \\ Email: thoyib1958@gmail.com \\ ${ }^{3}$ STEBIS IGM Palembang \\ Email: chandras@stebisigm.ac.id
}

\begin{abstract}
This study aims to determine and analyze the influence of Determination of Organizational Performance of Regional Devices of the Government of Musi Banyuasin Regency in South Sumatra Province The data in this study were collected using the method of observation and survey through interviews and with the help of research instruments in the form of questionnaires totaling 144 examinations which were distributed directly to 52 local government organizations in Musi Banyuasin Regency, which were addressed directly to regional heads. work units, secretaries and section heads who work for local government organizations. Data in this study will be analyzed using multiple linear regression with the help of SPSS software version 24.0. To test the validity and reliability of research instruments used the Correlation Item-Total Correction and Cronvach's Alpha. In addition, data normalization is also tested using the normal probability plot. The results of this study indicate that of these four variables; Clarity of budget targets, internal control systems, good governance, and professionalism have a positive and significant effect on organizational performance either partially or simultaneously.
\end{abstract}

Keywords: Clarity of Budget Objectives, Internal Control System, Good Governance, Professionalism, Regional Device Organizational Performance.

\section{DASAR PEMIKIRAN}

Berawal dari tuntutan masyarakat agar terciptanya good governance dalam penyelenggaraan pemerintahan berbasis otonomi daerah di Indonesia, menjadikan kinerja sebagai bagian yang sangat penting guna memberikan pertanggungjawaban atas rencana ataupun pelaksanaan anggaran yang berhak diketahui oleh publik (Silalahi, 2017). Menurut PP No 90 Tahun 2010, dalam rangka mengikuti dinamika perkembangan proses penyusunan Rancangan Anggaran Pendapatan dan Belanja Negara berbasis kinerja, perlu dilakukan penyempurnaan terhadap mekanisme penyusunan Rencana Kerja dan Anggaran Kementrian Negara/ Lembaga sehingga menjadi lebih transparan dan akuntabel. 
2 | Indra. S., Sulaiman, Chandra. S., M. Thoyib, Ade L., Adit A Penentuan Kinerja Organisasi......

Banyak fakor yang dapat mempengaruhi kinerja Organisasi Pemerintah Daerah (OPD) salah satu diantarnya kejelasan sasaran anggran. Kejelasan sasaran anggaran dapat memberikan kemudahan bagi (OPD) untuk menyusun rencana kegiatan dengan tujuan yang ingin dicapai oleh pemerintah daerah, sehingga anggaran dapat dijadikan tolak ukur pencapaian kinerja dengan kata lain kualitas anggaran daerah dapat menentukan kualitas pelaksanaan fungsi-fungsi pemerintah daerah (Nadirsyah,dkk. 2012) dalam (Widyatana, 2014). Kualitas proses pengukuran kinerja sangat dipengaruhi oleh kualitas proses penganggaran karena pengukuran kinerja merupakan mata rantai yang berkesinambungan dengan penganggaran (Putra, 2013).

Faktor yang berpengaruh terhadap kinerja organisasi salah satunya adalah sistem pengendalian internal. Sistem pengendalian intern dan penerapan prinsip-prinsip good corporate governance menyatakan bahwa terdapat hubungan antara komitmen organisasi, pengendalian intern dan penerapan good governance terhadap kinerja organisasi. Dalam PP No. 60 Tahun 2008, Sistem Pengendalian Intern adalah proses yang integral pada tindakan dan kegiatan yang dilakukan secara terus menerus oleh pimpinan dan seluruh pegawai untuk memberikan keyakinan memadai atas tercapainya tujuan organisasi melalui kegiatan yang efektif dan efisien, keandalan (Prasetyono \& Kompyurini, 2007)

Berdasarkan PP No. 101 tahun 2000 menyatakan good governance adalah pemerintahan yang mengembangkan dan menetapkan prinsip-prinsip profesionalitas, akuntabilitas, transparansi, pelayanan prima, demokrasi, efisiensi, efektivitas, supremasi hukum dan dapat diterima oleh seluruh masyarakat. Terselenggaranya good governance merupakan prasyarat utama untuk mewujudkan aspirasi masyarakat dalam mencapai tujuan dan cita-cita bangsa dan negara. Melaksanakan good governance yang baik tentu kinerja suatu organisasi akan berjalan dengan baik dan sesuai dengan tujuan dari organisasi tersebut. Hal ini dapat diberikan kesimpulan bahwa apabila pelaksanaan good governance ditingkatkan maka otomatis dapat meningkatkan kinerja organisasi itu sendiri (Mulyawa, 2015).

Dengan demikian pegawai harus profesionalisme sehingga dapat menyesuaikan dengan kebutuhan masyarakat, tepatnya perubahan sosial diikuti dengan perubahan manajemen pemerintahan. Para pegawai pada dasarya media atau instrument 
Ekonomica Sharia Volume 5 Nomor 1 Edisi Agustus 2019 | 3

penyelenggaraan pemerintahan yang bekerja untuk kepentingan masyarakat secara keseluruhan atau merupakan jembatan antara kepentingan masyarakat dan kepentingan pemerintah. Para pegawai harus professional dalam melayani masyarakat karena profesionalisme pegawai merupakan arah serta tujuan dari tata kelola pemerintahan yang baik.

Instruksi Presiden Nomor. 7 Tahun 1999 tentang Akuntanbilitas Kinerja Instansi Pemerintah. Mewajibkan setiap instansi untuk mempertanggungjawabkan pelaksanaan tugas pokok dan fungsinya serta kewenangan pengelolaan sumber daya dengan didasarkan suatu perencanaan sasaran strategik yang ditetapkan oleh masing-masing instansi. Media yang digunakan untuk pelaporan akuntabilitas tersebut adalah Laporan Akuntabilitas Kinerja Instansi Pemerintah (LAKIP) yang merupakan hasil dari suatu proses Sistem Akuntabilitas Kinerja Instansi Pemerintah (SAKIP). Sistem akuntabilitas kinerja instansi pemerintah (SAKIP) merupakan instrumen yang digunakan instansi pemerintah untuk menjawab kewajiban tersebut yang terdiri dari berbagai komponen yang merupakan satu kesatuan, yaitu perencanaan stratejik, pengukuran kinerja, pelaporan kinerja, dan Pemanfaatan informasi kinerja (M.Amar, 2012). Pemerintah dalam menyusun suatu rencana strategi juga harus memperhatikan dasar hukum dan peraturan yang berlaku. Banyak sekali kasus penyelewengan Laporan Akuntabilitas Kinerja Instansi Pemerintah (LAKIP) yang tidak sesuai dengan hukum bahkan ada juga Satuan Kerja Pemerintah Daerah (SKPD) yang tidak melaporkan Laporan Akuntabilitas Kinerja Instansi Pemerintah (LAKIP).

Berdasarkan hasil evaluasi analisis capaian akuntabilitas kinerja pemerintah Kabupaten Musi Banyuasin tahun 2018, hasil keseluruhan evaluasi akuntabilitas kinerja Organisasi Pemerintah Daerah (OPD) menunjukkan bahwa Pemerintah Kabupaten Musi Banyuasin memperoleh nilai 61,12 atau predikat $\mathrm{B}$, penilaian tersebut menunjukkan tingkat efektivitas dan efisiensi penggunaan anggaran dibandingkan dengan capaian kinerjanya, kualitas pembangunan budaya kinerja birokrasi dan penyelenggaraan pemerintahan yang berorientasi pada hasil di Pemerintah Kabupaten Musi Banyuasin sudah menunjukan hasil yang baik, tetapi belum optimal. Komponen yang dinilai di antaranya perencanaan kerja, pengukuran kinerja pelaporan kinerja, evaluasi internal, dan capaian kerja. Untuk perencanaan kinerja meraih skor 20.79, pengukuran kinerja 
4 | Indra. S., Sulaiman, Chandra. S., M. Thoyib, Ade L., Adit A Penentuan Kinerja Organisasi.....

14.70, pelaporan kinerja 10.75, evaluasi internal 6.20, dan capaian kinerja 8.67 ditahun 2018. Organisasi Pemerintah Daerah (OPD) yang tercatat sebanyak 7 Perangkat Daerah (PD) meraih predikat A, tercatat sebanyak 8 Pemerintah Daerah (PD) yang meraih predikat $\mathrm{B}$ dan tercatat meraih predikat $\mathrm{C}$ tercatat ada 10 Pemerintah Daerah (PD).

Berdasarkan hasil evaluasi Pemerintah Kabupaten Musi Banyuasin masih belum optimal untuk meningkatkan kinerja Organisasi Pemerintah Daerah karena masih banyak yang pemerintah daerah yang mendapatkan predikat $\mathrm{C}$ dalam penilaian Kinerja Pemerintah Daerah Kabupaten Musi Banyuasin. Berdasarkan uraian di atas masih perlu dilakukan penelitian atas variabel; Kejelasan Sasaran Anggaran, Sitem Pengendalian Intern, Good Governance dan Profesionalisme karena hal tersebut menjadi tujuan utama mendukung good government governance yang sekaligus mempengaruhi dalam usaha meningkatkan akuntabilitas atau Kinerja Organisasi Pemerintah Daerah, maka dari itu peneliti tertarik untuk meneliti tentang "Determinasi Kinerja Organisasi Perangkat Daerah Pemerintahan Kabupaten Musi Banyuasin Provinsi Sumatera Selatan”

\section{TINJAUAN PUSTAKA}

\section{Kejelasan Sasaran Anggaran}

Menurut (Andarias, 2009) dalam (Yulianti, 2014) menyatakan kejelasan sasaran anggaran digunakan untuk mengatur perilaku pegawai. Pelaksana anggaran akan menjadi bingung dan tidak puas dalam bekerja jika terdapat ketidakjelasan sasaran anggaran sehingga menyebabkan pelaksana anggaran tidak termotivasi untuk mencapai kinerja yang diharapkan. Kenis juga menyatakan bahwa anggaran tidak hanya sebagai alat perencanaan, pengendalian biaya dan pendapatan dalam pusat pertanggungjawaban dalam suatu organisasi, sisi lain anggaran juga merupakan alat bagi manajerial OPD untuk mengkoordinasikan, mengkomunikasikan, mengevaluasi kinerja dan memotivasi bawahannya.

Menurut Halim dan Kusufi (2014:55) anggaran berbasis kinerja merupakan teknik penganggaran dalam sektor publik yang disusun untuk mengatasi berbagai kelemahan yang terdapat dalam anggaran tradisional, khususnya kelemahan yang disebabkan oleh adanya tolak ukur yang dapat digunakan untuk mengukur kinerja dalam pencapaian 
Ekonomica Sharia Volume 5 Nomor 1 Edisi Agustus 2019 | 5

tujuan dan sasaran pelayanan publik. Anggaran pendekatan kinerja sangat menekankan pada konsep value for money dan pengawasan atas kinerja output.

Unsur-Unsur Pokok Anggaran Berbasis Kinerja menurut Badan Pendidikan dan Pelatihan Keuangan (BPPK, 2008) unsur-unsur anggaran berbasis kinerja, yaitu:

1. Pengukuran Kinerja (dimensi) Menentukan Program dan Kegiatan dengan Jelas, dengan indikator ;Sistem Informasi yang Memadai, Pihak Eksternal (independen), Mengukur Kinerja yang Strategis (key performance indicators).2. Penghargaan dan Hukuman (Reward and Punishment) dimensi,dengan indikator; Penerapan Insentif atas Kinerja yang Dicapai dan Hukuman atas Kegagalannya,Penerapan Efisiensi (savings),Penahanan atas Penerimaan yang Diperoleh oleh Suatu Lembaga.

3. Kontrak Kerja (dimensi), dengan indikator; Definisi yang jelas terhadap pelayanan yang dikontrakkan, Kewenangan yang ada bagi pihak Kementerian Negara/Lembaga untuk mengelola sumber daya yang ada.

4. Kontrol Eksternal dan Internal (dimensi, dengan indikator; Adanya pemisahan antara lembaga kontrol dan lembaga pengguna anggaran, Kontrol dilakukan pada input,output, dan outcome, Kontrol dilakukan sebelum dan sesudah anggaran digunakan.

5. Pertanggungjawaban Manajemen (dimensi), dengan indikator; input,Prinsip dasar di dalam sistem ini adalah manajer pengguna anggaran harus diberi kebebasan penuh bisa akuntabilitas atas pencapaian output yang ingin dicapai.

\section{Sistem Pengendalian Internal}

Dalam PP No 60 tahun 2008, kegiatan pengendalian membantu memastikan bahwa arah pimpinan Instansi Pemerintah dilaksanakan. Kegiatan pengendalian harus efisien dan efektif dalam pencapaian tujuan organisasi serta sesuai dengan ukuran, kompleksitas dan sifat dari tugas dan fungsi suatu instansi pemerintah yang bersangkutan. Kegiatan pengendalian intern terdiri atas review atas kinerja instansi pemerintah yang bersangkutan.

Sistem akuntansi keuangan daerah adalah sistem akuntansi yang meliputi proses pencatatan, penggolongan, penafsiran, peringkasan transaksi atau kejadian keuangan 
6 | Indra. S., Sulaiman, Chandra. S., M. Thoyib, Ade L., Adit A Penentuan Kinerja Organisasi..... serta pelaporan keuangan dalam rangka pelaksanaan APBD (Erlina dan Rasdianto, 2013). Didalam Pasal 232 Peraturan Menteri Dalam Negeri No. 13 Tahun 2006 tentang Pedoman Pengelolaan Keuangan Daerah, mengemukakan bahwa Sistem akuntansi pemerintahan daerah tersebut meliputi serangkaian prosedur mulai dari proses pengumpulan data, pencatatan, pengikhtisaran, sampai dengan pelaporan keuangan dalam rangka pertanggungjawaban pelaksanaan APBD yang dapat dilakukan secara manual atau menggunakan aplikasi komputer.

Menurut Halim dalam Usman (2014) menjelaskan secara garis besar sistem akuntansi keuangan daerah meliputi sebagai berikut: 1. Prosedur Akuntansi Penerimaan Kas, 2. Prosedur Akuntansi Pengeluaran Kas, 3. Prosedur Akuntansi Aset Tetap/Barang Milik Daerah, 4. Prosedur Akuntansi Selain Kas, 5. Penyajian Laporan Keuangan

\section{Good Governance}

Kinerja pegawai yang mencermin pada prinsip good governance dapat mendukung terlaksananya pemerintahan yang demokratis dan masyarakat dapat memiliki kepercayaannya terhadap kinerja pegawai, bahwa disetiap kinerja pegawai yang mencerminkan pada prinsip-prinsip good governance diharapkan dapat memberikan pelayanan publik yang lebih baik kepada masyarakat (Rumalolas, 2018). Menurut Wiranto (2012:1) dalam Auditya, Lucy dkk (2013) Good governance dapat dipahami sebagai implementasi otoritas politik, ekonomi, dan administratif dalam proses manajemen berbagai urusan publik pada berbagai level dalam suatu negara".

Mardiasmo (2004) dalam Risal Rumalolas (2018) Good Governance adalah suatu tatanan kehidupan berbangsa dan bernegara yang pola sikap dan pola tindak pelakunya dilandasi prinsip-prinsip dan karakteristik tertentu. Suatu penyelenggaraan negara yang mengimplementasikan good governance berarti penyelenggaraan negara tersebut mendasarkan diri pada prinsip-prinsip partisipasi, pemerintahan berdasarkan hukum, transparansi, responsivitas, orientasi konsensus, keadilan, efektivitas dan efisiensi, akuntabilitas, visi strategis dan saling keterkaitan. 
Ekonomica Sharia Volume 5 Nomor 1 Edisi Agustus $2019 \mid 7$

\section{Profesionalisme}

Dalam TAP MPR RI Nomor IV/MPR/1999 tentang Garis-Garis Besar Haluan Negara (GBHN) dinyatakan Meningkatkan Kualitas aparatur negara dengan memperbaiki kesejahteraan dan keprofesionalan serta memberlakukan sistem karir berdasarkan prestasi dengan prinsip memberikan penghargaan dan sanksi. Setelah itu, untuk merealisasikan arah kebijakan GBHN dimaksud, maka Undang-Undang Nomor 25 Tahun 2000 tentang Program Pembangunan Nasional Tahun 2000-2004 merumuskan Program Pemerintahan yang Baik dengan menetapkan kebijakan sebagai berikut:

Untuk mewujudkan pemerintahan yang baik, diperlukan upaya peningkatan kelembagaan dan ketatalaksanaan yang mencakup pembaharuan sistem dan struktur pemerintahan, baik di pusat maupun di daerah, serta penyesuaian jumlah PNS dan meningkatkan kapasitas sumber daya manusia peneyelenggara negara yang meliputi peningkatan ethos kerja, integritas, dan kualitasnya agar mampu memberikan pelayanan kepada masyarakat secara optimal.

Menurut (Harefa, 2014) profesionalisme adalah sebagai berikut :

profesionalisme pertama-tama adalah soal sikap. Lalu dia mengatakan ada beberapa hal yang dapat dianggap mewakili sikap profesionalisme yaitu, keterampilan tinggi, pemberian jasa yang berorientasi pada kepentingan umum, pengawasan yang ketat atas perilaku kerja dan suatu sistem balas jasa yang merupakan lambing prestasi kerja.

\section{Kinerja Organiasi Perangkat Daerah}

Secara etimologis, kinerja adalah sebuah kata yang dalam bahasa Indonesia berasal dari kata dasar "kerja" yang menerjemahkan kata dari bahasa asing prestasi, bisa pula berarti hasil kerja. Sehingga pengertian kinerja dalam organisasi merupakan jawaban dari berhasil atau tidaknya tujuan organisasi yang telah ditetapkan (www.wikipedia.com, 2018)

Menurut Bastian (2010:88) istilah Akuntabilitas berasal dari istilah bahasa inggris accountability yang berarti pertangungjawaban atau keadaan untuk dipertanggung jawabkan atau keadaan untuk diminta pertanggung jawaban. Akuntabilitas kinerja merupakan salah satu kata kunci bagi terwujudnya good governance dalam pengelolaan organisasi publik. 
8 Indra. S., Sulaiman, Chandra. S., M. Thoyib, Ade L., Adit A Penentuan Kinerja Organisasio....

Keputusan Kepala LAN No.239/IX/6/8/2003 tentang Pedoman Penyusunan Pelaporan Akuntabilitas Kinerja Instansi Pemerintah, menjelaskan bahwa akuntabilitas kinerja instansi pemerintah adalah perwujudan kewajiban suatu instansi pemerintah untuk mempertanggungjawabkan keberhasilan dan kegagalan pelaksanaan misi organisasi dalam mencapai sasaran dan tujuan yang telah ditetapkan melalui sistem pertanggungjawaban secara periodik.

Dalam Modul Pusat Pendidikan dan Pelatihan Pengawasan Badan Pengawasan Keuangan dan Pembangunan (Pusdiklatwas BPKP, 2007:10) menjelaskan bahwa sistem akuntabilitas kinerja instansi pemerintah merupakan suatu tatanan, instrumen, dan metode pertanggungjawaban yang intinya meliputi tahap-tahap Penetapan perencanaan stratejik, pengukuran kinerja, pelaporan kinerja, dan pemanfaatan informasi kinerja bagi perbaikan kinerja secara berkesinambungan.

\section{Penelitian Terdahulu}

Sebagai bahan referensi, dalam penelitian ini dicantumkan beberapa hasil penelitian terdahulu yang relevan. Berikut ini hasil penelitian terdahulu yang berkaitan dengan Pengaruh Kejelasan Sasaran Anggaran, Sistem Pengendalian Intern, Good Governance, Profesionalisme Terhadap Kinerja Organisasi Perangkat Daerah dapat dilihat pada tabel 2.1 di bawah ini:

Tabel 2.1

Penelitian Terdahulu

\begin{tabular}{|c|l|l|}
\hline o & \multicolumn{1}{|c|}{ Judul Penelitian } & \multicolumn{1}{c|}{ Hasil (Kesimpulan) } \\
\hline & $\begin{array}{l}\text { Luh Febri Indrayani, Putu Gede Diatmika, } \\
\text { dan Made Arie Wahyuni (2017). }\end{array}$ & $\begin{array}{l}\text { hasil penelitian ini menunjukkan Komitmen } \\
\text { Organisasi(X1), Kejelasan Sasaran Anggaran(X2) }\end{array}$ \\
$\begin{array}{l}\text { Pengaruh Komitmen Organisasi, Kejelasan } \\
\text { Efektivitas Penegendalian Internal(X3) berpengaruh } \\
\text { Sasaran Anggaran, dan Efektivitas } \\
\text { signifikan positif secara parsial maupun simultan }\end{array}$ & $\begin{array}{l}\text { Penegendalian Internal Terhadap } \\
\text { terhadap Akuntabilitas Kinerja Organisasi Perangkat }\end{array}$ \\
$\begin{array}{l}\text { Akuntabilitas Kinerja Organisasi Perangkat } \\
\text { Publik (Studi Empiris pada Satuan Kerja } \\
\text { Perangkat Daerah Kabupaten Gianyar) }\end{array}$ & Publik (Y) pemerintah Kabupaten Gianyar. \\
\hline
\end{tabular}


Ekonomica Sharia Volume 5 Nomor 1 Edisi Agustus 2019 | 9

\begin{tabular}{|c|c|}
\hline $\begin{array}{l}\text { Fitrawati, Abdul Kahar dan Muh. Ikbal A } \\
\text { (2017) Pengaruh Kejelasan Sasaran } \\
\text { Anggaran dan Sistem Pengendalian Intern } \\
\text { Terhadap Akuntabilitas Kinerja Instansi } \\
\text { Pemerintah (Survei Pada Satuan Kerja } \\
\text { Perangkat Daerah (Skpd) Kabupaten Parigi } \\
\text { Moutong) }\end{array}$ & $\begin{array}{l}\text { hasil penelitian ini menunjukkan Kejelasan } \\
\text { Sasaran Anggaran (X1) Sistem Pengendalian } \\
\text { Intern (X2) berpengaruh signifikan positif secara } \\
\text { parsial maupun simultan terhadap akuntabilitas } \\
\text { Akuntabilitas Kinerja Instansi Pemerintah (Y) } \\
\text { pemerintah Kabupaten Parigi Moutong. }\end{array}$ \\
\hline $\begin{array}{l}\text { Ni Kadek Rina Primayoni, Made Pradana } \\
\text { Adiputra, dan Edy Sujana (2014) Pengaruh } \\
\text { Kejelasan Sasaran Anggaran dan Efektifitas } \\
\text { Pengendalian Internal } r \text { Terhadap } \\
\text { Akuntabilitas Kinerja Instansi Pemerintah } \\
\text { (Studi Kasus pada SKPD Kabupaten } \\
\text { Klungkung) }\end{array}$ & $\begin{array}{l}\text { hasil penelitian ini menunjukkan kejelasan sasaran } \\
\text { anggaran (X1), efektivitas pengendalian internal (X2) } \\
\text { berpengaruh signifikan positif secara parsial maupun } \\
\text { simultan terhadap akuntabilitas kinerja instansi } \\
\text { pemerintah (Y) pemerintah Kabupaten Klungkung }\end{array}$ \\
\hline $\begin{array}{l}\text { Asrini (2017). Pengaruh Akuntabilitas } \\
\text { Publik, Kejelasan Sasaran Anggaran dan } \\
\text { Partisipasi Penyusunan Anggaran Terhadap } \\
\text { Kinerja Skpd di Pemerintah Daerah Kota } \\
\text { Palu }\end{array}$ & $\begin{array}{l}\text { hasil penelitian ini menunjukkan Akuntabilitas Publik } \\
\text { (X1), Kejelasan Sasaran Anggaran (X2) dan } \\
\text { Partisipasi Penyusunan Anggaran (X3) berpengaruh } \\
\text { signifikan positif secara parsial maupun simultan } \\
\text { terhadap akuntabilitas Kinerja Skpd (Y) Pemerintah } \\
\text { Daerah Kota Palu }\end{array}$ \\
\hline $\begin{array}{l}\text { Chici Claraini (2017). Pengaruh Good } \\
\text { Governance, Sistem Pengendalian Intern } \\
\text { Pmerintah dan Gaya Kepemimpinan } \\
\text { Terhadap Kinerja Pemerintah Daerah (Studi } \\
\text { Pada Satuan Kerja Perangkat Daerah } \\
\text { Kabupaten Rokan Hilir) }\end{array}$ & $\begin{array}{l}\text { hasil penelitian ini menunjukkan Good Governance } \\
\text { (X1), Sistem Pengendalian Intern Pmerintah (X2) } \\
\text { Gaya Kepemimpinan (X3) berpengaruh signifikan } \\
\text { positif secara parsial maupun simultan terhadap } \\
\text { Kinerja Pemerintah Daerah (Y) pemerintah } \\
\text { Kabupaten Rokan Hilir }\end{array}$ \\
\hline $\begin{array}{lll}\text { Abdullah. Adri }(2017) & \text { Pengaruh } \\
\text { Profesionalisme dan Komitmen Organisasi } \\
\text { Terdapat Kinerja Pegawai pada Kantor } \\
\text { Inspektor Provinsi Sulawesi Selatan }\end{array}$ & $\begin{array}{l}\text { Hasil penelitian ini menunjukkan Profesionalisme } \\
\text { (X1) Komitmen Organisasi (X2) berpengaruh } \\
\text { signifikan positif secara parsial maupun simultan } \\
\text { terhadap Pegawai pada Kantor Inspektor (Y) Provinsi } \\
\text { Sulawesi Selatan }\end{array}$ \\
\hline $\begin{array}{l}\text { Risal Rumalolas (2018) Pengaruh Good } \\
\text { Governance Terhadap Kinerja Pegawai } \\
\text { Satuan Kerja Perangkat Daerah di } \\
\text { Kabupaten Seram Bagian Timur Provinsi } \\
\text { Maluku }\end{array}$ & $\begin{array}{l}\text { hasil penelitian ini menunjukkan Good Governance } \\
\text { (X1) berpengaruh signifikan positif secara parsial } \\
\text { maupun simultan terhadap Kinerja Pegawai Satuan } \\
\text { Kerja Perangkat Daerah (Y) Kabupaten Seram } \\
\text { Bagian Timur Provinsi Maluku }\end{array}$ \\
\hline $\begin{array}{l}\text { Edipson Bayer Silalahi (2017). Pengaruh } \\
\text { Kejelasan Sasaran Anggaran, Pengendalian } \\
\text { Internal, dan Sistem Pelaporan Terhadap } \\
\text { Akuntabilitass Kinerja Instansi Pemerintah } \\
\text { Dengan Komitmen Organisasi Sebagai } \\
\text { Variabel Moderating Pada Pemerintah } \\
\text { Kabuapaten Serdang Bedagai }\end{array}$ & $\begin{array}{l}\text { hasil penelitian ini menunjukkan Sasaran Anggaran } \\
\text { (X1) Pengendalian Internal(X2) berpengaruh } \\
\text { signifikan positif secara parsial maupun simultan } \\
\text { terhadap Akuntabilitass Kinerja Instansi Pemerintah } \\
\text { Dengan Komitmen Organisasi (Y) Pemerintah } \\
\text { Kabuapaten Serdang Bedagai }\end{array}$ \\
\hline
\end{tabular}

Sumber : Diolah dari berbagai sumber, 2019

\section{Paradigma dan Hipotesa Penelitian}

Berdasarkan uraian dari latar belakang, tinjauan pustaka dan teori-teori yang telah dijelaskan pada bab terdahulu, maka dibentuk kerangka penelitian sebagai berikut: 


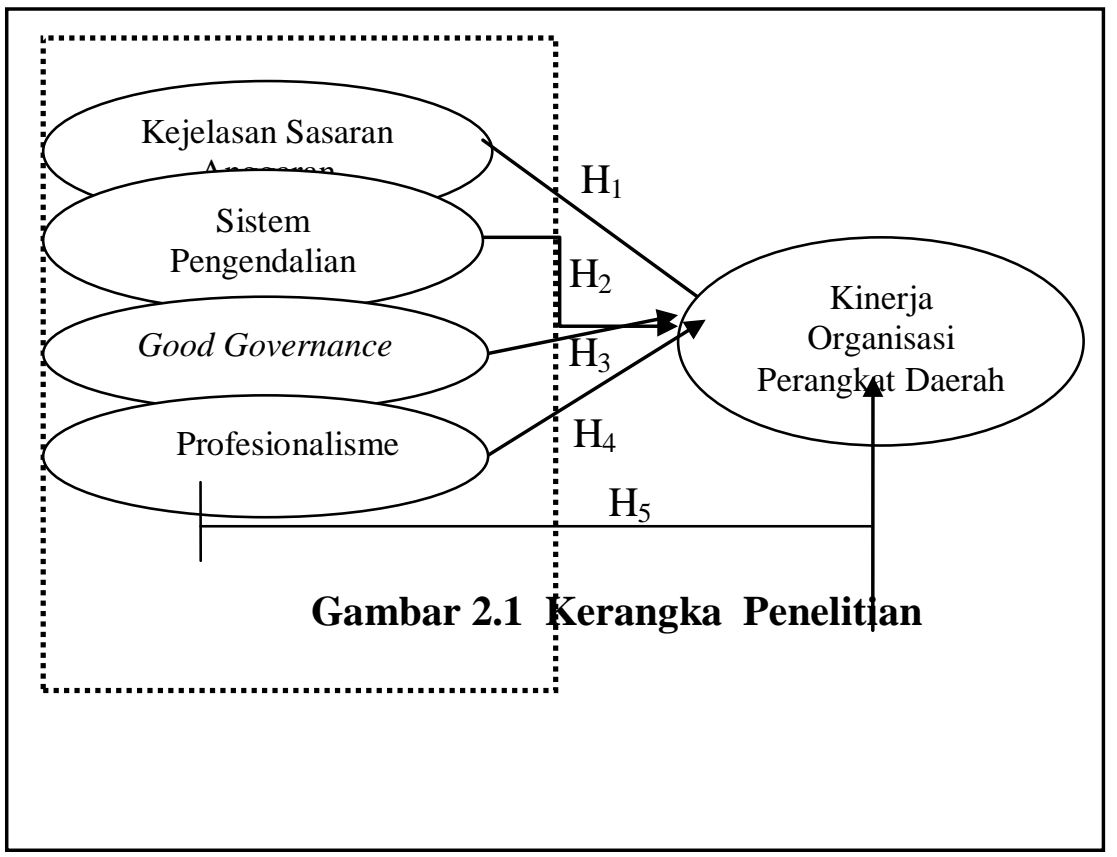

Menurut Sugiyono (2011:20) "hipotesis merupakan jawaban sementara terhadap rumusan masalah penelitian yang kebenarannya harus diuji secara empiris". Adapun hipotesis yang diajukan dalam penelitian ini adalah sebagai berikut: "Diduga pengaruh positif dan signifikan Kejelasan Sasaran Anggaran, Sistem Pengendalian Internal, Good Governance Profesionalisme secara parsial maupun bersam-sama terhadap Kinerja Organisasi Pemerintahan Daerah Kabupaten Musi Provinsi Banyuasin Sumatera Selatan.

\section{METODE PENELITIAN}

Penelitian ini menurut tingkat eksplanasinya adalah penelitian Asosiatif dengan analisis kuantitatif menggunakan tipe kausalitas karena di dalam penelitian ini akan diteliti hubungan yang bersifat sebab-akibat dari variabel independen dan variabel dependen. Metode kuantitatif adalah metode yang data penelitiannya berupa angkaangka dan analisis menggunakan statistik (Sugiyono,2016:7) Penelitian ini dilakukan di Satuan Kerja Perangkat Daerah (Organisasi Pemerintah daerah) Kabupaten Musi Banyuasin Sumatera Selatan dan dilaksanakan antara bulan Januari 2019 sampai dengan bulan Desember 2019. 
Ekonomica Sharia Volume 5 Nomor 1 Edisi Agustus 2019| 11

\section{Populasi dan sampel Penelitian}

Populasi dalam penelitian ini adalah Organisasi Perangkat Daerah (OPD) Kabupatan Musi Banyuasin yang mana setiap OPD diambil sebagai unit penelitiannya yaitu: 1) Kepala OPD, 2) Sekretaris Dinas, 3) Kepala Bidang Keuangan dan 4) Kepala Bidang Perencanaan di 52 OPD yang berada di Kabupatan Musi Banyuasin dengan sampel sebanyak 208.

Dalam penelitian ini peneliti mengambil sampel yang mewakili populasi secara tepat. Jadi total keseluruhan sampel yang diambil adalah sebanyak 208 orang. Teknik penarikan sampel dalam penelitian ini menggunakan purposive sampling, yang merupakan bagian dari nonprobability sampling.

\section{Teknik Pengumpulan Data}

Teknik pengumpulan data merupakan teknik untuk melakukan pengumpulan, pencatatan dan penyajian data. Teknik pengumpulan data dengan teknik interview, observasi dan penyebaran kuisioner dalam hal ini kesetiap OPD yang telah ditetapkan.

\section{Definisi variabel dan Operasional Variabel Penelitian}

Dalam penelitian ini, digunakan dua macam variabel penelitian yaitu satu variabel terikat (dependent variable) dan empat variabel bebas (independent variable). Variabel terikat atau variabel tergantung (dependent variable) yang digunakan dalam penelitian ini adalah Kinerja Organisasi Perangkat Daerah Kabupaten Musi Banyuasin dengan simbul (Y) serta variabel bebas (independent variable) adalah Kejelasan Sasaran Anggaran (X1), Sistem Sistem Pengendalian Internal (X2), Good Governance (X3), Profesionalisme (X4). Dengan definisi variabel, dimensi serta indikator, untuk membentuk instrumen penelitian (kuisioner) dengan jawaban tertutup menggunakan skala pengukuran data interval Likert. Terlihat di dalam tabel opearasional variabel penelitian berikut. 
12 | Indra. S., Sulaiman, Chandra. S., M. Thoyib, Ade L., Adit A Penentuan Kinerja Organisasi....•

Tabel 3.1

Operasionalisasi Variabel

\begin{tabular}{|c|c|c|c|c|}
\hline No & Variabel & Dimensi & Indikator & $\begin{array}{c}\text { Item } \\
\text { kuisione } \\
\mathbf{r}\end{array}$ \\
\hline \multirow[t]{5}{*}{1} & \multirow{5}{*}{$\begin{array}{l}\text { Kejelasan Sasaran Anggaran (X1) } \\
\text { Menurut Halim dan Kusufi } \\
\text { (2014:55) } \\
\text { Anggaran berbasis kinerja } \\
\text { merupakan teknik penganggaran } \\
\text { dalam sektor publik yang disusun } \\
\text { untuk mengatasi berbagai } \\
\text { kelemahan yang terdapat dalam } \\
\text { anggaran tradisional, khususnya } \\
\text { kelemahan yang disebabkan oleh } \\
\text { adanya tolak ukur yang dapat } \\
\text { digunakan untuk mengukur kinerja } \\
\text { dalam pencapaian tujuan dan } \\
\text { sasaran pelayanan publik. } \\
\text { Anggaran pendekatan kinerja } \\
\text { sangat menekankan pada konsep } \\
\text { value for money dan pengawasan } \\
\text { atas kinerja output. }\end{array}$} & 1. Pengukuran Kinerja & $\begin{array}{l}\text { 1. Program dan Kegiatan dengan Jelas } \\
\text { 2. Sistem Informasi yang Memadai } \\
\text { 3. Pihak Eksternal (independen) } \\
\text { 4. Kinerja yang Strategis (key } \\
\text { performance indicators). }\end{array}$ & $1 \mathrm{~s} . \mathrm{d} 4$ \\
\hline & & $\begin{array}{l}\text { 2. Penghargaan dan } \\
\text { Hukuman (Reward } \\
\text { and Punishment) }\end{array}$ & $\begin{array}{l}\text { 5. Penerapan Insentif Hukuman } \\
\text { 6. Penerapan Efisiensi (savings) } \\
\text { 7. Penahanan }\end{array}$ & 5 s.d 7 \\
\hline & & 3. Kontrak Kinerja & $\begin{array}{l}\text { 8. Definisi kontrak pelayanan jelas } \\
\text { 9. Kewenangan bagi pihak } \\
\text { Kementerian Negara/Lembaga }\end{array}$ & 8 s.d 9 \\
\hline & & $\begin{array}{l}\text { 4. Kontrol Eksternal dan } \\
\text { Internal }\end{array}$ & $\begin{array}{l}\text { 10. pemisahan antara lembaga kontrol } \\
\text { dan lembaga pengguna anggaran } \\
\text { 11. Kontrol pada input, output, dan } \\
\text { outcome } \\
\text { 12. Kontrol sebelum dan sesudah } \\
\text { anggaran digunakan. }\end{array}$ & 10s.d 12 \\
\hline & & $\begin{array}{l}\text { 5. Pertanggung jawaban } \\
\text { Manajemen. }\end{array}$ & $\begin{array}{l}\text { 13. Tanggung jawab pada output } \\
\text { 14. Kebebasan penuh atas pencapaian } \\
\text { output yang ingin dicapai. }\end{array}$ & $\begin{array}{ll}13 & \text { s.d } \\
14 & \end{array}$ \\
\hline \multirow[t]{5}{*}{2} & \multirow{5}{*}{$\begin{array}{l}\text { Sistem Pengendalian Internal (X2) } \\
\text { Sistem Pengendalian Internal } \\
\text { Didalam Pasal 232 Peraturan } \\
\text { Menteri Dalam Negeri No. 13 } \\
\text { Tahun 2006 tentang Pedoman } \\
\text { Pengelolaan Keuangan Daerah, } \\
\text { mengemukakan bahwa Sistem } \\
\text { akuntansi pemerintahan daerah } \\
\text { tersebut meliputi serangkaian } \\
\text { prosedur mulai dari proses } \\
\text { pengumpulan data, pencatatan, } \\
\text { pengikhtisaran, sampai dengan } \\
\text { pelaporan keuangan dalam rangka } \\
\text { pertanggungjawaban pelaksanaan } \\
\text { APBD yang dapat dilakukan secara } \\
\text { manual atau menggunakan aplikasi } \\
\text { komputer. }\end{array}$} & $\begin{array}{l}\text { 1. Prosedur Akuntansi } \\
\text { Penerimaan Kas }\end{array}$ & $\begin{array}{ll}\text { 1. } & \text { Pencatatan } \\
\text { 2. } & \text { Pengikhitisaran } \\
\text { 3. } & \text { Pelaporan }\end{array}$ & $1 \mathrm{s.d} 3$ \\
\hline & & $\begin{array}{ll}\text { 2. Prosedur Akuntansi } \\
\text { Pengeluaran Kas }\end{array}$ & $\begin{array}{l}\text { 4. Pencatatan } \\
\text { 5.penggolongan dan peringkasan } \\
\text { 6. Pelaporan }\end{array}$ & 4s.d 6 \\
\hline & & $\begin{array}{l}\text { 3. Prosedur Akuntansi } \\
\text { Aset } \\
\text { Tetap/BarangMilik } \\
\text { Daerah }\end{array}$ & $\begin{array}{ll}\text { 7. Perolehan } & \\
\text { 8.Pemeliharaan, } & \text { Rehabilitas, } \\
\text { Penghapusan, } & \text { Pemindahtanganan, } \\
\text { Perubahan } & \text { klasifikasi dan } \\
\text { penyusutan } & \end{array}$ & $7 \mathrm{s.d} 8$ \\
\hline & & $\begin{array}{ll}\text { 4. } & \text { Prosedur } \\
\text { Selain Kas } & \text { Akuntansi }\end{array}$ & $\begin{array}{l}\text { 9. Pencatatan } \\
\text { 10. Pengikhitisaran } \\
\text { 11. Pelaporan } \\
\end{array}$ & 9s.d 11 \\
\hline & & $\begin{array}{l}\text { 5. Penyajian } \\
\text { Keuangan }\end{array}$ & $\begin{array}{l}\text { 12. Memahami penyajian laporan } \\
\text { keuangan } \\
\text { 13. Memaham sistem pencatatan } \\
\text { double entry }\end{array}$ & $\begin{array}{l}12 \\
14\end{array}$ \\
\hline
\end{tabular}




\begin{tabular}{|c|c|c|c|c|}
\hline & & & $\begin{array}{l}\text { 14. Memahami prosedur kas basis ke } \\
\text { akrual basis }\end{array}$ & \\
\hline \multirow[t]{4}{*}{3} & \multirow{4}{*}{$\begin{array}{l}\text { Good Governance (X3) Menurut } \\
\text { Alice } N \text {, Miring'u, dan Muoria } \\
\text { Esther } T \text { (2011) Definisi ini } \\
\text { menegaskan bahwa tata kelola } \\
\text { pemerintahan yang baik merupakan } \\
\text { pengelolaan suber daya atau } \\
\text { urusan negara secara cerdas } \\
\text { dengan cara yang terbuka, } \\
\text { transparan, akuntabel, adil, dan } \\
\text { tanggap terhadap keinginan dan } \\
\text { aspirasi masyarakat. }\end{array}$} & 1. Struktur Tata Kelola & $\begin{array}{l}\text { 1. struktur tata kelola menjadi acuan } \\
\text { seleksi } \\
\text { 2. Struktur tata kelola melakukan } \\
\text { peran dan tanggung jawabnya } \\
\text { secara konsisten } \\
\text { 3. garis pelaporan diantara struktur } \\
\text { tata kelola }\end{array}$ & 1 s.d 3 \\
\hline & & 2. Otonomi & $\begin{array}{l}\text { 4. kewenangan untuk menyusun } \\
\text { anggaran dan program } \\
\text { 5. kewenangan untuk melakukan } \\
\text { evaluasi atas kegiatan } \\
\text { 6. kewenangan untuk melakukan } \\
\text { penyusunan program } \\
\text { 7. kewenangan untuk kriteria } \\
\text { penerimaan pegawai }\end{array}$ & $4 s . d 7$ \\
\hline & & 3. Akuntabilitas & $\begin{array}{l}\text { 8. melakukan pemantauan kinerja } \\
\text { 9. Sistem tata kelola akuntabilitas staf } \\
\text { 10. kompetensi Pegawai sesuai standar } \\
\text { ditetapkan oleh regulator } \\
\text { 11. melaporkan kegiatan secara rutin } \\
\text { 12. Sosialisasi dan pengkomunikasian } \\
\text { visi dilakukan secara terprogram }\end{array}$ & $8 s . d 12$ \\
\hline & & 4. Transparan & $\begin{array}{l}\text { 13. menjamininformasi berkualitas } \\
\text { 14. Data dan informasi diakses } \\
\text { masyarakat dan stakeholder lainya }\end{array}$ & 13s.d14 \\
\hline \multirow[t]{4}{*}{4} & \multirow{4}{*}{$\begin{array}{l}\text { Profesionalisme (X4) } \begin{array}{r}\text { Menurut } \\
\text { bahwa }\end{array} \\
\text { (Harefa, 2014) pertama-tama } \\
\text { profesionalisme soal sikap. Lalu dia } \\
\text { adalah soalu } \\
\text { mengatakan ada beberapa hal yang } \\
\text { dapat dianggap mewakili sikap } \\
\text { profesionalisme yaitu, } \\
\text { keterampilan tinggi, pemberian } \\
\text { jasa yang berorientasi pada } \\
\text { kepentingan umum, pengawasan } \\
\text { yang ketat atas perilaku kerja dan } \\
\text { suatu sistem balas jasa yang } \\
\text { merupakan lambing prestasi kerja. }\end{array}$} & 1. Sifat Karakteristik & $\begin{array}{l}\text { 1. Pengukuran Profesi } \\
\text { 2. Jenis Pekerjaan }\end{array}$ & 1 s.d 2 \\
\hline & & 2. Disiplin & $\begin{array}{l}\text { 3. Optimal } \\
\text { 4. Efisien }\end{array}$ & 3 s.d 4 \\
\hline & & 3. Etika Profesi & $\begin{array}{ll}5 & \begin{array}{l}\text { kepribadian dan tanggung jawab } \\
\text { profesi }\end{array} \\
6 & \text { Integritas }\end{array}$ & 5 s.d 6 \\
\hline & & $\begin{array}{l}\text { 4. } \text { Kualitas } \\
\text { Profesionalisme }\end{array}$ & $\begin{array}{l}\text { 7. Tingkat Pendidikan } \\
\text { 8. kemampuan }\end{array}$ & 7 s.d 8 \\
\hline \multirow[t]{3}{*}{5} & \multirow{3}{*}{ 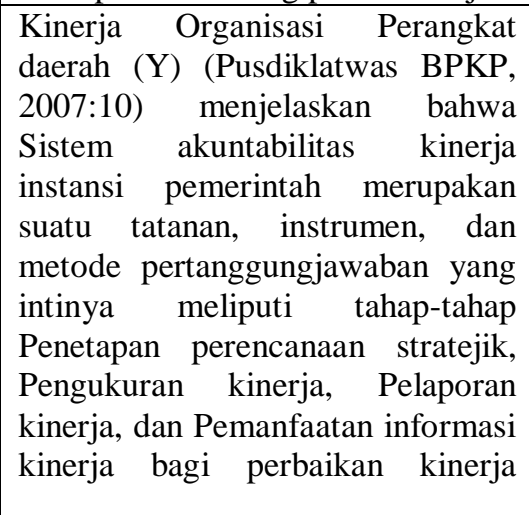 } & $\begin{array}{l}\text { 1. Penetapan perencanaan } \\
\text { stratejik. }\end{array}$ & $\begin{array}{l}\text { 1. Keterkaitan kinerja dengan } \\
\text { program } \\
\text { 2. Kejelasan sasaran anggaran } \\
\text { 3. Visi dan misi program }\end{array}$ & 1 s.d 3 \\
\hline & & 2. ${ }_{\text {kinerja }}$ Pengukuran & $\begin{array}{l}\text { 4. Penetapan indikator kinerja } \\
\text { 5. Kontrol indikator kinerja }\end{array}$ & 4 s.d 5 \\
\hline & & 3. Pelaporan kinerja. & $\begin{array}{ll}\text { 6. } & \text { Analisa keuangan } \\
\text { 7. } & \text { Membuat laporan } \\
\text { 8. } & \text { Pengecekan jalannya program } \\
& \text { yang telah dilaksanakan }\end{array}$ & $6 s . d 8$ \\
\hline
\end{tabular}


14 | Indra. S., Sulaiman, Chandra. S., M. Thoyib, Ade L., Adit A Penentuan Kinerja Organisasi....•

\begin{tabular}{|l|l|l|l|l|}
\hline secara berkesinambungan & $\begin{array}{l}\text { 4. Pemanfaatan } \\
\text { informasi kinerja bagi } \\
\text { perbaikan kinerja } \\
\text { secara } \\
\text { berkesinambungan }\end{array}$ & $\begin{array}{l}\text { 9. Mengakomodir perubahan } \\
\text { 10. LAKIP }\end{array}$ & 9 s.d \\
\hline
\end{tabular}

Sumber : data diolah, 2019

Teknik pengukuran yang digunakan untuk mengubah data kualitatif dari kuesioner menjadi suatu urutan data kuantitatif adalah skala lima tingkatan Likert-type yang menghasilkan data interval (Cooper \& Schindler, 2017). Sebelum kuisioner disebarkan kepada responden maka dilakukan uji validitas dan reliabilitas dengan menggunakan minimal 30 responden ahli dibidangnya, hasil dari tes kuisioner tersebut menunjukan butir-butir petanyaan dan variabel penelitian terindikasi valid dan reliabel. Selanjutnya setelah data terkumpul sebagai syarat uji hipotesis maka dilakukan uji klasik. Uji asumsi klasik ini terdiri dari uji normalitas, multikolonieritas, dan heteroskedastisitas.

\section{Analisis Regresi Linear Berganda}

Analisis regresi linier berganda adalah analisis untuk mengukur besarnya pengaruh antara dua atau lebih variabel independen terhadap satu variabel dependen dan memprediksi variabel dependen dengan menggunakan variabel independen (Priyanto, 2012), dan model penelitian ini menggunakan regresi linier berganda yang merujuk pada Priyatno (2012).

$$
Y=a+b_{1} X_{1}+b_{2} X_{2}+b_{3} X_{3}+b_{4} X_{4}+e_{i}
$$

Keterangan :

$$
\begin{aligned}
\mathrm{Y} & =\text { Akuntabilitas Pengelolaan Keuangan Daerah } \\
\mathrm{a} & =\text { konstanta } \\
\mathrm{X}_{1} & =\text { Kejelasan Sasaran Anggaran } \\
\mathrm{X}_{2} & =\text { Sistem Pengendalian Intern } \\
\mathrm{X}_{3} & =\text { Good Governance } \\
\mathrm{X}_{4} & =\text { Profesionalisme } \\
\mathrm{b} 1 & =\text { Koefisien Regresi Kejelasan Sasaran Anggaran } \\
\mathrm{b} 2 & =\text { Koefisien Regresi Sistem Pengendalian Intern } \\
\text { b3 } & =\text { Koefisien Regresi Good Governance } \\
\text { b4 } & =\text { Koefisien Regresi Profesionalisme }, \quad \mathrm{e}_{\mathrm{i}}=\text { Error }
\end{aligned}
$$




\section{Uji Signifikan Parsial (Uji t)}

Uji t bertujuan untuk mengetahui besarnya pengaruh masing-masing variabel independen secara individual terhadap variabel dependen. Langkahlangkah pengujian adalah sebagai berikut:

a. Menetukan hipotesis: $H o=0$ : variabel independen $(\mathrm{X})$ secara individual tidak berpengaruh terhadap variabel dependen $(\mathrm{Y}), \mathrm{Ha} \neq 0$ : variabel independen $(\mathrm{X})$ secara individual berpengaruh terhadap variabel dependen (Y).

b. Membuat Kesimpulan: Bila t-hitung $\leq \mathrm{t}$-tabel atau sig $>\alpha(0,05)$, maka Ho diterima dan Ha ditolak. Artinya secara parsial variabel independen tidak berpengaruh terhadap variabel dependen. Bila t-hitung $\geq \mathrm{t}$-tabel atau $\operatorname{sig}<\alpha(0,05)$, maka Ho ditolak dan Ha diterima. Artinya secara parsial variabel independen berpengaruh terhadap variabel dependen.

\section{Uji Signifikan Simultan (Uji F)}

Uji $\mathrm{F}$ bertujuan untuk menguji atau mengetahui pengaruh semua variabel independen terhadap variabel dependen. Langkah-langkah pengujian adalah sebagai berikut:

1. Menetukan hipotesis : Ho=0 : semua variabel independen $(\mathrm{X})$ secara simultan tidak berpengaruh terhadap variabel dependen $(\mathrm{Y}), \mathrm{Ha} \neq 0$ : semua variabel independen (X) secara simultan berpengaruh terhadap variabel dependen (Y).

2. Membuat Kesimpulan: Bila F-hitung $\leq$ F-tabel atau sig $>\alpha(0,05)$, maka Ho diterima dan Ha ditolak. Artinya seluruh variabel independen secara simultan tidak berpengaruh terhadap variabel dependen.Bila F-hitung $\geq$ F-tabel atau sig $<\alpha(0,05)$, maka Ho ditolak dan Ha diterima. Artinya seluruh variabel independen secara simultan berpengaruh terhadap variabel dependen

\section{Koefisien Determinasi (Adjusted $\mathbf{R}^{2}$ )}

Menurut Priyatno (2012) Koefisien Determinasi (Adjusted $\mathrm{R}^{2}$ ) digunakan untuk mengukur seberapa jauh kemampuan model dalam menerangkan variasi variabel dependen. Nilai koefisiens determinasi adalah nol dan satu. Nilai $\mathrm{AR}^{2}$ yang kecil berarti kemampuan variabel-variabel independen memberikan hampir semua informasi yang dibutuhkan untuk memprediksi variasi variabel dependen. 
16 | Indra. S., Sulaiman, Chandra. S., M. Thoyib, Ade L., Adit A Penentuan Kinerja Organisasi.....

\section{HASIL PENELITIAN DAN PEMBAHASAN}

\section{Analisis Deskriptif}

Deskripsi data penelitian yaitu menunjukkan hasil yang diperoleh berdasarkan jawaban responden terhadap masing-masing indikator pengukur variabel. Variabelvariabel yang dioperasionalkan dalam penelitian terdiri dari Kejelasan Sasaran Anggaran (X1), Sistem Pengendalian Intern (X2), Good Governance (X3), Profesionalisme (X4) dan Kinerja Organisasi Perangkat Daerah (Y). Skor masingmasing alternative jawaban dari varabel penelitian telah ditentukan dengan nilai minimal 1 dan maksimal 5, maka interval dapat dihitung sebagaiberikut:

1. Menentukan skor tertingi dan skor terendah Skor tertinggi $=5$, Skor terendah $=1$

2. Menentukan rentang data, Rentang data $=$ data tertinggi - skor terendah, $=5-1,=4$

3. Menentukan panjang kelas iterval,Rentang data $=5$, Range (panjang kelas interval) $=\frac{4}{5}=0,8$

Di bawah ini akan dijelaskan deskriptif jawaban responden pada variabel penelitian. Kriteria yang digunakan untuk mengetahui kondisi variabel-variabel penelitian secara menyeluruh dapat dilihat melalui skor rata-rata pada tabel 4.1 berikut:

Tabel 4.1.Kategori Jawaban Responden

\begin{tabular}{|c|c|}
\hline Interval & Kategori \\
\hline $1,00-1,80$ & Sangat Tidak Setuju \\
\hline $1,80-2,60$ & Tidak Setuju \\
\hline $2,60-3,40$ & Cukup Setuju \\
\hline $3,40-4,20$ & Setuju \\
\hline $4,20-5,00$ & Sangat Setuju \\
\hline
\end{tabular}

Sumber: diolah dari kuesioner 2019

Deskripsi hasil jawaban kuesioner untuk variabel-variabel penelitian di OPD Kabupaten Musi Banyuasin ditunjukan variabel Kejelasan sasaran anggaran pada tabel 4.2.

Tabel 4.2.Kejelasan Sasaran Anggaran (X1)

\begin{tabular}{|c|c|c|c|c|}
\hline Interval & Frekuensi & \% & \multicolumn{2}{|c|}{ Keterangan } \\
\hline $1,00-1,80$ & 0 & 0 & Sangat Tidak Setuju & \\
\cline { 1 - 3 } $1,80-2,60$ & 0 & 0 & Tidak Setuju $: 3,832$ \\
\cline { 1 - 3 } $2,60-3,40$ & 15 & 10,4 & Netral & \multirow{2}{*}{ Satandar Deviation: 0,36120} \\
\hline $3,40-4,20$ & 106 & 73,6 & Setuju & \\
\hline $4,20-5,00$ & 23 & 16,0 & Sangat Setuju & \\
\hline
\end{tabular}




\begin{tabular}{|c|c|c|c|c|}
\hline Total & 144 & 100 & & \\
\hline
\end{tabular}

Sumber : Diolah dari lampiran, 2019

Berdasarkan tabel 4.2 di atas dapat dilihat bahwa dari 144 sampel yang digunakan dalam penelitian ini, Kejelasan Sasaran Anggaran nilai rata-rata sebesar 3,832 diketahui bahwa nilai rata-rata tersebut termasuk dalam kategori setuju. Variabel Kejelasan Sasaran Anggaran yang mempunyai nilai terendah dengan interval 2,60-3,40 dengan jumlah responden sebanyak 15 orang dan jika dipersentasekan sebesar 10,4\%. Nilai tertinggi dari variabel ini berada pada interval 3,40-4,20 dengan jumlah responden sebanyak 106 orang dan persentase sebesar 73,6\%.

Tabel 4.3 Sistem Pengendalian Intern (X2)

\begin{tabular}{|c|c|c|c|c|}
\hline Interval & Frekuensi & \% & \multicolumn{2}{|c|}{ Keterangan } \\
\hline $1,00-1,80$ & 0 & 0 & Sangat Tidak Setuju & \multirow{2}{*}{ Mean: 4,220} \\
\cline { 1 - 2 } $1,80-2,60$ & 0 & 0 & Tidak Setuju & \\
\hline $2,60-3,40$ & 4 & 2,8 & Netral & \\
\hline $3,40-4,20$ & 54 & 37,5 & Setuju & Satandar Deviation: \\
\cline { 1 - 3 } $4,20-5,00$ & 86 & 59,7 & Sangat Setuju & \\
\hline Total & 144 & 100 & & \\
\hline
\end{tabular}

Sumber : Diolah dari lampiran, 2019

Berdasarkan tabel 4.3 Diatas dapat dilihat bahwa dari 144 sampel yang digunakan dalam penelitian ini, Sistem Pengendalian Intern nilai rata-rata sebesar 4,220 diketahui bahwa nilai rata-rata tersebut termasuk dalam kategori sangat setuju. Variabel Sistem Pengendalian Intern yang mempunyai nilai terendah dengan interval 2,60-3,40 dengan jumlah responden sebanyak 4 orang dan jika dipersentasekan sebesar 2,8\%. Nilai tertinggi dari variabel ini berada pada interval 4,20-5,00 dengan jumlah responden sebanyak 86 orang dan persentase sebesar $59,7 \% \%$.

Tabel 4.4 Good Governance (X3)

\begin{tabular}{|c|c|c|c|}
\hline Interval & Frekuensi & \% & Keterangan \\
\hline $1,00-1,80$ & 0 & 0 & Sangat Tidak Setuju \\
\hline $1,80-2,60$ & 0 & 0 & Tidak Setuju \\
\hline $2,60-3,40$ & 5 & 3,5 & Netral \\
\hline $3,40-4,20$ & 62 & 43,1 & Setuju \\
\hline $4,20-5,00$ & 77 & 53,5 & Sangat Setuju \\
\hline Total & 144 & 100 & 4,179 \\
\hline Mean Satandar Deviation & & 0,37984 \\
\hline
\end{tabular}

Sumber : Diolah dari lampiran, 2019 
18 | Indra. S., Sulaiman, Chandra. S., M. Thoyib, Ade L., Adit A Penentuan Kinerja Organisasi.....

Berdasarkan tabel 4.4 di atas dapat dilihat bahwa dari 144 sampel yang digunakan dalam penelitian ini, Good Governance nilai rata-rata sebesar 4,179 diketahui bahwa nilai rata-rata tersebut termasuk dalam kategori sangat setuju. Variabel Good Governance yang mempunyai nilai terendah dengan interval 2,60-3,40 dengan jumlah responden sebanyak 5 orang dan jika dipersentasekan sebesar 3,5\%. Nilai tertinggi dari variabel ini berada pada interval 4,20-5,00 dengan jumlah responden sebanyak 77 orang dan persentase sebesar 53,5\%.

Tabel 4.5 Profesionalisme (X4)

\begin{tabular}{|c|c|c|c|}
\hline Interval & Frekuensi & \% & Keterangan \\
\hline $1,00-1,80$ & 0 & 0 & Sangat Tidak Setuju \\
\hline $1,80-2,60$ & 0 & 0 & Tidak Setuju \\
\hline $2,60-3,40$ & 4 & 2,8 & Netral \\
\hline $3,40-4,20$ & 58 & 40,3 & Setuju \\
\hline $4,20-5,00$ & 82 & 56,9 & Sangat Setuju \\
\hline Total & 144 & 100 & 4,229 \\
\hline Mean & & & 0,40811 \\
\hline
\end{tabular}

Sumber : Diolah dari lampiran, 2019

Berdasarkan tabel 4.5 di atas dapat dilihat bahwa dari 144 sampel yang digunakan dalam penelitian ini, Profesionalisme nilai rata-rata sebesar 4,229 diketahui bahwa nilai rata-rata tersebut termasuk dalam kategori sangat setuju. Variabel Profesionalisme yang mempunyai nilai terendah dengan interval 2,60-3,40 dengan jumlah responden sebanyak 4 orang dan jika dipersentasekan sebesar 2,8\%. Nilai tertinggi dari variabel ini berada pada interval 4,20-5,00 dengan jumlah responden sebanyak 82 orang dan persentase sebesar 56,9\%.

Tabel 4.6 Kinerja Organisasi Perangkat (Y)

\begin{tabular}{|c|c|c|c|}
\hline Interval & Frekuensi & $\mathbf{\%}$ & Keterangan \\
\hline $1,00-1,80$ & 0 & 0 & Sangat Tidak Setuju \\
\hline $1,80-2,60$ & 0 & 0 & Tidak Setuju \\
\hline $2,60-3,40$ & 0 & 0 & Netral \\
\hline $3,40-4,20$ & 4 & 2,8 & Setuju \\
\hline $4,20-5,00$ & 140 & 97,2 & Sangat Setuju \\
\hline Total & 144 & 100 & 4,681 \\
\hline Mean & & & 0,22271 \\
\hline
\end{tabular}


Sumber : Diolah dari lampiran, 2019

Berdasarkan tabel 4.6 di atas dapat dilihat bahwa dari 144 sampel yang digunakan dalam penelitian ini, Kinerja Organisasi Perangkat Daerah nilai rata-rata sebesar 4,681 diketahui bahwa nilai rata-rata tersebut termasuk dalam kategori sangat setuju. Variabel Kinerja Organisasi Perangkat Daerah yang mempunyai nilai terendah dengan interval 3,40 - 4,20 dengan jumlah responden sebanyak 4 orang dan jika dipersentasekan sebesar 2,8\%. Nilai tertinggi dari variabel ini berada pada interval 4,20-5,00 dengan jumlah responden sebanyak 140 orang dan persentase sebesar 97,2\%.

\section{Analisis Induktif}

\section{Analisis Regresi Linier Berganda}

Dalam penelitian ini terdapat empat variabel independen yaitu kejelasan sasaran anggaran, sistem pengendalian intern, Good Governance, dan profesianlisme dan satu variabel dependen yaitu kinerja organisasi pernagkata daerah. Dengan demikian liner berganda dinyatakan dalam rumus persamaan matematika sebagi berikut :

$$
Y=a+b_{1} X_{1}+b_{2} X_{2}+b_{3} X_{3}+b_{4} X_{4}+e_{i}
$$

Tabel 4.7 Output Coefficient

\begin{tabular}{|c|c|c|c|c|c|c|}
\hline \multirow{2}{*}{\multicolumn{2}{|c|}{ Model }} & \multicolumn{2}{|c|}{$\begin{array}{c}\text { Unstandardized } \\
\text { Coefficients }\end{array}$} & \multirow{3}{*}{$\begin{array}{c}\begin{array}{c}\text { Standardized } \\
\text { Coefficients }\end{array} \\
\text { Beta }\end{array}$} & \multirow[t]{2}{*}{$t$} & \multirow[t]{2}{*}{ Sig. } \\
\hline & & $\mathrm{B}$ & Std. Error & & & \\
\hline \multirow[t]{5}{*}{1} & (Constant) & 1,885 & ,236 & & 7,984 & ,000 \\
\hline & $\begin{array}{l}\text { Kejelasan Sasaran } \\
\text { Anggaran }\end{array}$ & ,081 & ,037 &, 132 & 2,195 &, 030 \\
\hline & $\begin{array}{l}\text { Sistem Pengendalian } \\
\text { Internal }\end{array}$ &, 172 & ,036 & ,292 & 4,814 &, 000 \\
\hline & Good Governance &, 185 & 035 & ,315 & 5,212 & ,000 \\
\hline & Prefesionalisme & ,233 & 033 & ,429 & 7,148 &, 000 \\
\hline
\end{tabular}

a. Dependent Variable: Kinerja Organisasi Perangkat Daerah

Sumber : Output SPSS Versi 24 diolah, 2019

Berdasarkan tabel 4.7 di atas diperoleh persamaan sebagai berikut (Sanusi, 2016:144) :

$$
Y=1,885+0,132 X_{1}+0,292 X_{2}+0,315 X_{3}+0,429 X_{4}+e_{i}
$$

Persamaan regresi berganda di atas menunjukkan koefisien regresi dari $\beta 1, \beta 2, \beta 3$ dan $\beta 4$ bernilai positif. Hal ini menunjukkan variabel-variabel independen apabila ditingkatkan maka akan menimbulkan peningkatan pada variabel dependennya. 
20 | Indra. S., Sulaiman, Chandra. S., M. Thoyib, Ade L., Adit A Penentuan Kinerja Organisasio....

a. Nilai konstanta sebesar 1,885 artinya jika variabel kejelasan sasaran anggaran, sistem pengendalian intern, good governance dan profesionalisme nilai 0 , maka nilai kinerja organisasi perangkat daerah nilainya positif sebesar 1,885.

b. Nilai koefisien regresi untuk variabel kejelasan sasaran anggaran sebesar 0,132. Artinya bahwa setiap peningkatan kejelasan sasaran anggaran sebesar satu satuan variabel, maka tingkat kinerja organisasi perangkat daerah akan meningkat sebesar 0,132, dengan asumsi variabel bebas lainnya konstan.

c. Nilai koefisien regresi untuk variabel sistem pengendalian intern sebesar 0,292. Artinya bahwa setiap peningkatan sistem pengendalian intern sebesar satu satuan variabel, maka tingkat kinerja organisasi perangkat daerah akan meningkat sebesar 0,292 , dengan asumsi varaiabel bebas lainnya konstan.

d. Nilai koefisien regresi untuk variabel good governance sebesar 0,315. Artinya bahwa setiap peningkatan good governance sebesar satu satuan variabel, maka tingkat kinerja organisasi perangkat daerah akan meningkat sebesar 0,315, dengan asumsi varaiabel bebas lainnya konstan.

e. Nilai koefisien regresi untuk variabel profesionalisme sebesar 0,429. Artinya bahwa setiap peningkatan profesionalisme sebesar satu satuan variabel, maka tingkat kinerja organisasi perangkat daerah akan meningkat sebesar 0,429, dengan asumsi varaiabel bebas lainnya konstan.

\section{Hasil Uji Signifikansi t (Uji t)}

Uji t atau uji koefisieen regresi secara parsial digunakan untuk mengetahui apakah secara parsial variabel independen berpengaruh secara signifikan atau tidak terhadap variabel dependen. Hasil uji t dalam penelitian ini dapat dilihat pada tabel 4.8 berikut ini :

Tabel 4.8 Hasil Uji Parsial (Uji t)

\begin{tabular}{|c|c|c|c|c|c|c|}
\hline \multicolumn{2}{|c|}{ Model } & \multicolumn{2}{|c|}{$\begin{array}{c}\text { Unstandardized } \\
\text { Coefficients }\end{array}$} & $\begin{array}{c}\text { Standardized } \\
\text { Coefficients }\end{array}$ & \multirow{2}{*}{$T$} & \multirow{2}{*}{ Sig. } \\
\cline { 3 - 7 } \multicolumn{2}{|c|}{} & B & Std. Error & Beta & & \\
\hline \multirow{2}{*}{1} & (Constant) & 1,885 &, 236 & & 7,984 &, 000 \\
\cline { 2 - 6 } & $\begin{array}{c}\text { Kejelasan Sasaran } \\
\text { Anggaran (X1) }\end{array}$ &, 081 &, 037 &, 132 & 2,195 &, 030 \\
\cline { 2 - 6 } & $\begin{array}{c}\text { Sistem Pengendalian } \\
\text { Internal (X2) }\end{array}$ &, 172 &, 036 &, 292 & 4,814 &, 000 \\
\hline
\end{tabular}


Ekonomica Sharia Volume 5 Nomor 1 Edisi Agustus 2019 | 21

\begin{tabular}{|c|c|c|c|c|c|}
\hline Good Governance (X3) & , 185 &, 035 & ,315 & 5,212 & ,000 \\
\hline Prefesionalisme (X4) & ,233 & ,033 & ,429 & 7,148 & ,000 \\
\hline
\end{tabular}
a. Dependent Variable : Kinerja Organisasi Perangkat Daerah

Sumber : Output SPSS Versi 24 diolah, 2019

Berdasarkan tabel 4.8 di atas hasil pengujian signifikansi secara parsial adalag sbagai berikut :

a. Koefisen regresi untuk variabel Kejelasan Sasaran Anggaran adalah 0,030. Koefisien ini signifikan pada $\propto=0,05$ dari $\mathrm{t}_{\text {tabel }}$ sebesar 1,656. Karena $\mathrm{t}_{\text {hitung }}>\mathrm{t}_{\text {tabel }}$ atau 2,195 $>1,656$ atau Sing $<\propto$ atau $0,030<0,05$ artinya, pengaruh Kejelasan Sasaran Anggaran terhadap Kinerja Organisasi Perangkat Daerah adalah Signifikan. Dengan demikian, hipotesis yang menyatakan bahwa adanya pengaruh Kejelasan Sasaran Anggaran secara parsial terhadap Kinerja Organisasi Perangkat Kabupaten Musi Banyuasin $\left(\mathrm{H}_{1}\right)$ dapat diterima atau teruji.

b. Koefisen regresi untuk variabel Sistem Pengendalian Internal adalah 0,000. Koefisien ini signifikan pada $\propto=0,05$ dari $t_{\text {tabel }}$ sebesar 1,656. Karena $t_{\text {hitung }}>t_{\text {tabel }}$ atau 4,814 > 1,656 atau Sing $<\propto$ atau 0,000 <0,05 artinya, pengaruh Sistem Pengendalian Internal terhadap Kinerja Organisasi Perangkat Daerah adalah Signifikan. Dengan demikian, hipotesis yang menyatakan bahwa adanya pengaruh Sistem Pengendalian Internal secara parsial terhadap Kinerja Organisasi Perangkat Kabupaten Musi Banyuasin $\left(\mathrm{H}_{2}\right)$ dapat diterima atau teruji.

c. Koefisen regresi untuk variabel Good Governance adalah 0,000. Koefisien ini signifikan pada $\propto=0,05$ dari $t_{\text {tabel }}$ sebesar 1,656. Karena $t_{\text {hitung }}>t_{\text {tabel }}$ atau 5,212> 1,656 atau Sing $<\propto$ atau $0,000<0,05$ artinya, pengaruh Sistem Pengendalian Internal terhadap Kinerja Organisasi Perangkat Daerah adalah Signifikan. Dengan demikian, hipotesis yang menyatakan bahwa adanya pengaruh Good Governance secara parsial terhadap Kinerja Organisasi Perangkat Kabupaten Musi Banyuasin $\left(\mathrm{H}_{3}\right)$ dapat diterima atau teruji.

d. Koefisen regresi untuk variabel Prefesionalisme adalah 0,000. Koefisien ini signifikan pada $\propto=0,05$ dari $t_{\text {tabel }}$ sebesar 1,656. Karena $t_{\text {hitung }}>t_{\text {tabel }}$ atau 7,148> 1,656 atau Sing $<\propto$ atau $0,000<0,05$ artinya, pengaruh Sistem Pengendalian Internal terhadap Kinerja Organisasi Perangkat Daerah adalah Signifikan. Dengan demikian, hipotesis yang menyatakan bahwa adanya pengaruh Prefesionalisme 
22 | Indra. S., Sulaiman, Chandra. S., M. Thoyib, Ade L., Adit A Penentuan Kinerja Organisasio....

secara parsial terhadap Kinerja Organisasi Perangkat Kabupaten Musi Banyuasin $\left(\mathrm{H}_{3}\right)$ dapat diterima atau teruji.

\section{Hasil Uji Signifikan F (Uji F)}

Uji $\mathrm{F}$ atau uji koefisieen regresi secara bersama-sama digunakan untuk mengetahui apakah secara bersama-sama variabel independen berpengaruh secara signifikan atau tidak terhadap variabel dependen. Hasil uji $\mathrm{F}$ dalam penelitian ini dpat dolihat pada tabel 4.9 berikut ini:

Tabel 4.9 Hasil Uji Signifikansi Simultan (Uji F)

\begin{tabular}{|c|c|c|c|c|c|c|}
\hline \multicolumn{7}{|c|}{ ANOVA $^{\text {a }}$} \\
\hline \multicolumn{2}{|c|}{ Model } & $\begin{array}{c}\text { Sum of } \\
\text { Squares }\end{array}$ & $D f$ & $\begin{array}{c}\text { Mean } \\
\text { Square }\end{array}$ & $F$ & Sig. \\
\hline \multirow{2}{*}{1} & Regression & 3,776 & 4 &, 944 & 39,560 &, $000^{\mathrm{b}}$ \\
\cline { 2 - 8 } & Residual & 3,317 & 139 &, 024 & & \\
\cline { 2 - 8 } & Total & 7,093 & 143 & & & \\
\hline
\end{tabular}

a. Dependent Variable : Kinerja Organisasi Perangkat Daerah

b. Predictors: (Constant), Kejelasan Sasaran Anggaran, Sistem Pengendalian Internal, Good Governance, Prefesionalisme

Sumber : Output SPSS Versi 24 diolah, 2019

Berdasarkan tabel 4.9 Tersebut dapat dilihat nialai $F_{\text {hitung }}$ sebesar 39,560 dan sig $=$ 0,000. Hal tersebut mengindikasikan bahwa $F_{\text {hitung }}<F_{\text {tabel }}$ atau 39,560 $>2,44$, sehingga dapat dinyatakan bahwa secara simultan variabel Kejelasan Sasaran Anggaran $\left(\mathrm{X}_{1}\right)$, Sistem Pengendalian Internal $\left(\mathrm{X}_{2}\right)$, Good Governance $\left(\mathrm{X}_{3}\right)$ dan Prefesionalisme $\left(\mathrm{X}_{4}\right)$ secara simultan mempengaruhi variabel dependen Kinerja Organisasi Perangkat Daerah (Y).

Sig $<\propto$ atau $0,000<0,05$ sehingga dapat disimpulkan bahwa secara keseluruhan variabel Kejelasan Sasaran Anggaran $\left(\mathrm{X}_{1}\right)$, Sistem Pengendalian Internal $\left(\mathrm{X}_{2}\right)$, Good Governance $\left(\mathrm{X}_{3}\right)$ dan Prefesionalisme $\left(\mathrm{X}_{4}\right)$ memiliki pengaruh yang signifikan terhadap variabel dependen Kinerja Organisasi Perangkat Daerah (Y) sebesar 0\%. Berdasarkan kesimpulan tersebut, maka hipotesis peneliti bahwa Kejelasan Sasaran Anggaran, Sistem Pengendalian Internal, Good Governance, Prefesionalisme mempengaruhi Kinerja Organisasi Perangkat Daerah Kabupaten Musi Banyuasin $\left(\mathrm{H}_{4}\right)$ dapat diterima. 


\section{Hasil Uji Koefisien Determinasi (Adjusted $\boldsymbol{R}^{2}$ )}

Koefisien detrminasi $\left(R^{2}\right)$ pada intinya mengukur seberapa jauh kemampuan model dalam menerangkan variasi variabel. Semakin tinggi nilai koefisien determinasi maka akan semakin baik pula kemampuan variabel independen dalam menjelaskan variabel dependen. Nilai koefisien determinasi adalah antara nol dan satu. Nilai $\mathrm{R}^{2}$ yang kecil berarti kemampuan variabel-variabel independen dalam menjelaskan variasi variabel dependen amat terbatas. Nilai yang mendekati satu berarti variabel-variabel independen memberikan hampir semua informasi yang dibutuhkan untuk memprediksikan variasi variabel dependen. Hasil koefisien determinasi pada penelitian ini disajikan pada tabel 4.10 berikut ini.

Tabel 4.10 Uji Koefisien Determinasi (Adjusted $\boldsymbol{R}^{2}$ )

\begin{tabular}{|r|c|r|r|r|}
\hline \multicolumn{5}{|c|}{ Model Summary $^{b}$} \\
\hline Model & $R$ & $R$ Square & $\begin{array}{l}\text { Adjusted } \\
\text { R Square }\end{array}$ & $\begin{array}{c}\text { Std. Error of the } \\
\text { Estimate }\end{array}$ \\
\hline 1 &, $730^{\mathrm{a}}$ &, 532 &, 519 & \\
\hline
\end{tabular}

a. Predictors: (Constant), Kejelasan Sasaran Anggaran, Sistem

Pengendalian Internal, Good Governance, Prefesionalisme

b. Dependent Variable : Kinerja Organisasi Perangkat Daerah Sumber : Output SPSS Versi 24 diolah, 2019

Koefisien determinasi merupakan angka yang meunjukan besar kontribusi pengaruh yang diberikan variabel bebas terhadap variabel terikat. Pada tabel 4.10 di atas, terlihat nilai $R$ Square yang diperoleh adalah sebesar 0,532 atau 53,2\%. Hasil tersebut menunjukan bahwa Kejelasan Sasaran Anggran (X1), Sistem Penegndalian Intern (X2), dan Good Governance (X3), Profesianlisme secara bersama-sama memberikan pengaruh sebesar 53,2\% terhadap Kinerja Organisasi Perangkat Daerah (Y), sedangkan sisanya sebesar $46,8 \%$ merupakan desebabkan faktor lain yang tidak diteliti dalam penelitian ini. 
24 | Indra. S., Sulaiman, Chandra. S., M. Thoyib, Ade L., Adit A Penentuan Kinerja Organisasio....

\section{KESIMPULAN DAN SARAN}

Berdasarkan hasil analisis dengan Kinerja Organisasi Perangkat Daerah pada Pemerintah Kabupaten Musi Banyuasin Provinsi Sumatera Selatan, maka dapat disimpulkan sebagai berikut:

Kejelasan Sasaran Anggaran, Sistem Pengendalian Intern, Good Governance dan Profesionalisme baik secara parsial maupun simultan berpengaruh positif dan signifikan, dan semua variabel independen memberikan kontribusi sebesar 51,9\% terhadap Kinerja Organisasi Perangkat Daerah pada Pemerintah Kabupaten Musi Banyuasin. sedangkan sisanya sebesar 46,8\% disebabkan oleh faktor lain yang tidak diteliti dalam penelitian ini.

Berdasarkan pada pembahasan dan kesimpulan di atas, maka peneliti menyarankan bahwa:

1. Pemerintah daerah terutama OPD kabupaten musi banyuasin sebaiknya melakukan pengkajian ulang mengenai Kejelasan Sasaran Anggaran, Sistem Pengendalian Intern, Good Governance dan Profesionalisme agar Kinerja Organisasi Perangkat Daerah Pemerintah Kabupaten Musi dapat terus ditingkatkan.

2. untuk peneliti selanjutnya diharapkan dapat menggali variabel-variabel lain yang juga berpengaruh terhadap kinerja Organisasi Perangkat Daerah seperti penerapan sistem akuntansi keuangan daerah, gaya kepemimpinan, kompetensi SDM. 


\section{DAFTAR PUSTAKA}

Adri, Abdullah. 2017. "Pengaruh Profesionalisme dan Komitmen Organisasi Terdapat Kinerja Pegawai pada Kantor Inspektor Provinsi Sulawesi Selatan”. Skripsi. universitas isalam negeri Alauddin Makassar.

Anwar, Sanusi. 2016. Metodologi Penelitian Bisnis. Cetakan Keenam. Jakarta: Salemba Empat.

Amir, M. 2012. Pengaruh Kejelasan Sasaran Anggaran, Pengendalian Akuntansi, dan Sistem Pelaporan terhadap Akuntabilitas Kinerja Instansi Pemerintah. AAJ 1 (2) (2012). Jurnal. Universitas Semarang.

Amelia, Ira dan Nur Azlina. 2014. "Pengaruh good governance dan pengendalian intern terhadap kinerja pemerintah daerah (studi pada satuan kerja pemerintah kabupaten pelalawan)." Jurnal Online Mahasiswa (JOM) Bidang Ilmu Ekonomi 1.1 : 1-15, Universitas Riau, Pekanbaru.

Auditya, Lucy dan Husaini. 2013. Pengaruh Akuntabilitas dan Transparansi Pengelolaan Keuangan Daerah Terhadap Kinerja Pemerintah Daerah. Jurnal Fairness Volume 3.

Asrini. 2017 "Pengaruh Akuntabilitas Publik, Kejelasan Sasaran Anggaran dan Partisipasi Penyusunan Anggaran Terhadap Kinerja Skpd di Pemerintah Daerah Kota Palu". e Jurnal Katalogis, Vol. 5 Nomor 1 Januari 2017.

Bastian, Indra. 2010. Akuntansi Sektor Publik Suatu Pengantar. Edisi Ketiga. Penerbit Erlangga :Jakarta

Badan Pendidikan dan Pelatihan Keuangan (BPPK). 2008. Pengukuran Kinerja, Suatu Tinjauan pada Instansi Pemerintah. Jakarta.

Bangun, Andarias. 2009. Pengaruh Partisipasi dalam Penyusunan Anggaran, Kejelasan Sasaran Anggaran dan Struktur Desentralisasi Terhadap Kinerja Manajerial SKPD dengan Pengawasan Internal Sebagai Variabel Pemoderasi (Studi Kasus pada Pemerintah Kabupaten Deli Serdang). Tesis

Baridwan, Zaki. 2010. Sistem Akuntansi Penyusunan Prosedur dan Metode. Edisi 5. Yogyakarta : BPPE

Chici Claraini. 2017 "Pengaruh Good Governance, Sistem Pengendalian Intern Pemerintah dan Gaya Kepemimpinan Terhadap Kinerja Pemerintah Daerah (Studi Pada Satuan Kerja Perangkat Daerah Kabupaten Rokan Hilir)". Jurnal. JOM Fekon, Vol.4 No.1 April 2017.

Cooper, D. R., \& Schindler, P. S. (2017). Metode Penelitian Bisnis. Yogyakarta: Salemba Empat.

Edy, Sujana, Made, Pradana, Adiputra, Ni Kadek, Rina, Primayoni. 2014. "Pengaruh Kejelasan Sasaran Anggaran dan Efektifitas Pengendalian Internal Terhadap Akuntabilitas Kinerja Instansi Pemerintah (Studi Kasus pada SKPD Kabupaten 
26 | Indra. S., Sulaiman, Chandra. S., M. Thoyib, Ade L., Adit A Penentuan Kinerja Organisasio.... Klungkung)" e-Journal S1 Ak Universitas Pendidikan Ganesha Jurusan Akuntansi Program S1 : Vol.2 No. 1 Tahun 2014.

Erlina dan Rasdianto, 2013, Akuntansi Keuangan Daerah Berbasis Akrual. Medan, Brama Ardian.

Ghozali, Imam. 2016. Aplikasi Analisis Multivariate Dengan Program SPSS. Semarang : BP Universitas Diponegoro Edisi 8.

Halim, Abdul dan .Muhammad Syam Kusufi. 2014. Teori, Konsep, dan Aplikasi Akuntansi Sektor Publik. Jakarta: Salemba Empat.

Harefe, H. 2014. Membangkitkan Etos Profesioanlisme. Jakarta : PT. Gramedia Pustaka Utama.

Ikbal A. Muh, Abdul Kahar, Fitrawati. 2017. "Pengaruh Kejelasan Sasaran Anggaran dan Sistem Pengendalian Intern Terhadap Akuntabilitas Kinerja Instansi Pemerintah (Survei Pada Satuan Kerja Perangkat Daerah (Skpd) Kabupaten Parigi Moutong)". e Jurnal Katalogis, Volume 5 Nomor 12, Desember 2017.

Mulyawan, Setia. 2015. Manajemen Keuangan. Bandung: CV PUSTAKA SETIA

Mulyadi. 2013. Sistem Akuntansi. Jakarta: Salemba Empat.

Mardiasmo. (2011). Akuntansi Sektor Publik, Yogyakarta: Penerbit Andi.

Narbuko, Chaoild dan abu ahmadi. 2009. Metodologi Penelitian. Jakarta, PT. Bumi Aksara.

Prasetyono dan Kompyurini. 2007. "Analisis Kinerja Rumah Sakit dengan Pendekatan Balanced Scorecard berdasarkan Komitmen Organisasi, Pengendalian Intern and Prinsip-prinsip Good Corporate Governance (GCG)". Jurnal. Makasar : Simposium Nasional Akuntansi.

Priyanto, Duwi. 2012. Cara Kilat Belajar Analisis Data Dengan SPSS 20. Yogyakarta: Andi.

Priyatno, Duwi. 2018. Panduan Mudah Olah Data Bagi Mahasiswa dan Umum SPSS. Yogyakarta: Andi

Putra, Deki. 2013. "Pengaruh Akuntabilitas Publik dan Kejelasan Sasaran Anggaran terhadap Kinerja Manajerial Satuan Kerja Perangkat Daerah (Studi Empiris pada SKPD Kota Padang)”. Skripsi.

Pusat Pendidikan dan Pelatihan Pengawasan Badan Pengawasan Keuangan dan Pembangunan (Pusdiklatwas BPKP). 2007. Akuntabilitas Instansi Pemerintah. Diklat Pembentukan Auditor Ahli. Edisi Kelima. 2007

Rahayu, Sri dan Andry Arifian Rachman. 2013. Penyusunan Anggaran Perusahaan. Yogyakarta: Graha Ilmu

Rusmalolas, Risal. 2018. "Pengaruh Good Governance Terhadap Kinerja Pegawai Satuan Kerja Perangkat Daerah di Kabupaten Seram Bagian Timur Provinsi Maluku". Skripsi. Universitas Muhammadiyah Surakarta. 
Silalahi Edipson Bayer. 2017. "Pengaruh Kejelasan Sasaran Anggaran, Pengendalian Internal, dan Sistem Pelaporan Terhadap Akuntabilitass Kinerja Instansi Pemerintah Dengan Komitmen Organisasi Sebagai Variabel Moderating Pada Pemerintah Kabuapaten Serdang Bedagai”. Skripsi. Universitas Sumatera Utara.

Sugiyono. 2016. Metode Penelitian Kuantitatif, Kualitatif, dan R\&D. Bandung: Alfabeta.

Wahyuni, Made, Arie, Diatmika, Gede, Putu, Indrayani, Luh Febr. 2017 "Pengaruh Komitmen Organisasi, Kejelasan Sasaran Anggaran, dan Efektivitas Penegendalian Internal Terhadap Akuntabilitas Kinerja Organisasi Perangkat Publik (Studi Empiris pada Satuan Kerja Perangkat Daerah Kabupaten Gianyare). -Journal S1 Ak Universitas Pendidikan Ganesha Jurusan Akuntansi Program S1 ; Vol. 8 No. 2 Tahun 2017.

Widyatana. (2014). pengaruh kejelasan saasaran anggaran, sistem pengendalian intern terhadap kinerja SKPD, 9.

\section{Peraturan Pemerintah :}

Peraturan Menteri Dalam Negeri Nomor 13 Tahun 2006 Tentang Pedoman Pengelolaan Keuangan Daerah

Republik Indonesia. Undang-Undang Nomor 90 Tahun 2010 Tentang Penyusunan Rencana Kerja Dan Anggaran Kementerian Negara/Lembaga

Republik Indonesia. Undang-Undang Nomor 60 Tahun 2008 Tentang Sistem Pengendalian Intern Pemerintah.

Republik Indonesia. Undang-Undang Nomor 8 Tahun 2006 Tentang Sistem Pengendalian Intern (SPI).

Republik Indonesia. Undang-Undang Nomor 101 Tahun 2000 Tentang prinsip-prinsip kepemerintahan yang baik

Republik Indonesia. Undang-Undang Nomor 25 Tahun 2000 Tentang Program Pembangunan Nasional (Propenas) Tahun 2000-2004.

Instruksi Presiden Republik Indonesia. Nomor 7 Tahun 1999 Tentang Akuntabilitas Kinerja Instansi Pemerintah.

Keputusan Kepala Lembaga Administrasi Negara Nomor 239/IX/6/2003 Tentang "Perbaikan Pedoman Penyusunan Laporan Akuntabilitas Kinerja Instansi Pemerintah".

\section{Referensi Online:}

https://sumateranews.co.id/akuntabilitas-kinerja-instansi-pemkab-muba-raih predikatb/. Diakses 10 Maret 2019.

http://www.definisi-pengertian.com/2015/07/profesionalisme-pegawai.html.

Diakses 12 Maret 2019.

https://id.wikipedia.org/wiki/Kinerja. Diakses 12 Maret 2019. 
